\title{
Use of ZnAl-Layered Double Hydroxide (LDH) to Extend the Service Life of Reinforced Concrete
}

\author{
Celestino Gomes ${ }^{1,2}{ }^{(}$, Zahid Mir $^{3}{ }^{(}$, Rui Sampaio ${ }^{1,2}\left(\mathbb{D}\right.$, Alexandre Bastos ${ }^{1,2, *(\mathbb{C})}$ \\ João Tedim ${ }^{1,2}\left(\mathbb{D}\right.$, Frederico Maia ${ }^{4}\left(\mathbb{D}\right.$, Cláudia Rocha $4(\mathbb{D})$ and Mário Ferreira ${ }^{1,2} \mathbb{( D}$ \\ 1 DEMaC-Department of Materials and Ceramic Engineering, Universidade de Aveiro, 3810-193 Aveiro, \\ Portugal; jcv.gomes@ua.pt (C.G.); ruisampaio@ua.pt (R.S.); joao.tedim@ua.pt (J.T.); mgferreira@ua.pt (M.F.) \\ 2 CICECO-Aveiro Institute of Materials, Universidade de Aveiro, 3810-193 Aveiro, Portugal \\ 3 Institute of Materials Research, Helmholtz-Zentrum Geesthacht, Max-Planck-Str. 1, 21502 Geesthacht, \\ Germany; Zahid.Mir@hzg.de \\ 4 Smallmatek-Small Materials and Technologies, Lda, 3810-075 Aveiro, Portugal; \\ frederico.maia@smallmatek.pt (F.M.); claudia.rocha@smallmatek.pt (C.R.) \\ * Correspondence: acbastos@ua.pt; Tel.: +351-234378146
}

Received: 22 March 2020; Accepted: 7 April 2020; Published: 9 April 2020

\begin{abstract}
This work investigated the use of ZnAl-layered double hydroxide (LDH) intercalated with nitrate or nitrite ions for controlling the corrosion of steel in reinforced concrete. The work started by analyzing the stability of the powder in the 1-14 $\mathrm{pH}$ range and the capacity for capturing chloride ions in aqueous solutions of different $\mathrm{pH}$. The effect of the $\mathrm{ZnAl}-\mathrm{LDH}$ on the corrosion of steel was studied in aqueous $0.05 \mathrm{M} \mathrm{NaCl}$ solution and in mortars immersed in $3.5 \% \mathrm{NaCl}$. It was found that the $\mathrm{LDH}$ powders dissolved partially at $\mathrm{pH}>12$. The $\mathrm{LDH}$ was able to capture chloride ions from the external solution, but the process was $\mathrm{pH}$-dependent and stopped at high $\mathrm{pH}$ due to the partial dissolution of $\mathrm{LDH}$ and the preferential exchange of $\mathrm{OH}^{-}$ions. These results seemed to imply that ZnAl-LDH would not work in the alkaline environment inside the concrete. Nonetheless, preliminary results with mortars containing ZnAl-LDH showed lower penetration of chloride ions and higher corrosion resistance of the steel rebars.
\end{abstract}

Keywords: LDH; layered double hydroxide; corrosion; concrete

\section{Introduction}

Reinforced concrete is the most common construction material in the world. It is a composite material, combining the high resistance to compression of hardened concrete with the high tensile strength and ductility of steel. Concrete and steel have very similar thermal expansion coefficients and, therefore, good adhesion is conserved between the two. Due to the excellent mechanical properties, low cost, and workability, reinforced concrete is shaping buildings and urban landscapes all over the globe [1].

Concrete is also very durable. Some buildings from the Roman Empire still exist 2000 years after construction. However, typical structures have a much more limited lifetime due to different degradation processes [2], which can be divided into physical (like those caused by freeze-thaw cycles or by fire), mechanical (due to erosion, abrasion, or impact), chemical (reactions with acids, ammonium, sulfate, $\mathrm{CO}_{2}$, or chloride), biological, and structural (e.g., overloading, cyclic loads, and soil settlement).

A major cause of the early degradation of reinforced concrete structures is the corrosion of steel rebars [2-4]. In general, the high alkalinity of concrete is an excellent environment for the passivity of steel. However, the ingress of aggressive agents like $\mathrm{CO}_{2}$ from the atmosphere or chloride ions from maritime environments and from deicing activity creates conditions for passivity breakdown. Carbon 
dioxide leads to the carbonation of concrete, which is accompanied by a decrease in $\mathrm{pH}$. When the front of low $\mathrm{pH}$ reaches the steel surface, the passivity is lost and uniform corrosion starts. Chloride ions, on the other hand, can disrupt the passive layer even at high $\mathrm{pH}$, if a threshold concentration is surpassed [5]. In these conditions, the corrosion is localized in the form of pitting, crevice, or stress corrosion cracking. The iron corrosion products are more voluminous than steel, which creates expansive stresses, leading to cracking at first and spallation of the concrete cover at the end. After that, steel becomes directly exposed to the atmospheric environment, and corrosion proceeds at a much faster rate.

Since the corrosion of steel rebars dramatically limits the service life of reinforced concrete, many forms of corrosion control are being explored [2-4,6,7], including the use of stainless steel or galvanized steel rebars, application of epoxy coating on steel rebars, cathodic protection, and addition of corrosion inhibitors to concrete (e.g., calcium nitrite, sodium benzoate, chromates, phosphates, polyphosphates, silicates, polycarboxylic acids, fatty acids emulsions, and alkanolamines). Corrosion can also be delayed by painting the surface of the concrete structure or using a thicker layer of concrete, separating the rebars and the environment. Less porous concrete (lower water/cement ratio), high quality cement, and the use of water and aggregates without soluble salts also contribute to extending the durability of the structure.

The direct addition of corrosion inhibitors to concrete may affect the curing process or the mechanical properties of the hardened material. Because of this possibility, the encapsulation of inhibitors in nano- or micro-reservoirs to be released only when needed (either with the onset of corrosion or in the presence of aggressive species) is a line of investigation worth pursuing.

Layered double hydroxides (LDHs) are one example of such nanostructured reservoirs. The LDH structure resembles the layered structure of $\mathrm{Mg}(\mathrm{OH})_{2}$ (brucite), with trivalent cations replacing some divalent $\mathrm{Mg}^{2+}$ cations [8,9]. The resulting excess of positive charge is compensated by anions between the metal hydroxide layers. Water is also in the interlayer space and helps to maintain the integrity of the structure by forming hydrogen bonds. The general formula of LDH is $\left[\mathrm{M}^{2+}{ }_{1-\mathrm{x}} \mathrm{M}^{3+}{ }_{\mathrm{x}}(\mathrm{OH})_{2}\right]^{+}\left[\mathrm{A}^{\mathrm{n}-}\right]_{\mathrm{x} / \mathrm{n}} \cdot \mathrm{yH}_{2} \mathrm{O}$ with $\mathrm{M}^{2+}=\mathrm{Mg}^{2+}, \mathrm{Ca}^{2+}, \mathrm{Zn}^{2+}, \mathrm{Ni}^{2+}$, or $\mathrm{Mn}^{2+}, \mathrm{M}^{3+}=\mathrm{Al}^{3+}$, $\mathrm{Fe}^{3+}, \mathrm{Cr}^{3+}$, or $\mathrm{Ga}^{3+}$, and $\mathrm{A}^{\mathrm{n}-}=\mathrm{CO}_{3}{ }^{2-}, \mathrm{OH}^{-}, \mathrm{Cl}^{-}, \mathrm{NO}_{2}{ }^{-}$, or $\mathrm{NO}_{3}{ }^{-}$, to name just a few. Hydrotalcite is a naturally-occurring $\mathrm{LDH}$ with the chemical formula $\mathrm{Mg}_{6} \mathrm{Al}_{2} \mathrm{CO}_{3}(\mathrm{OH})_{16} \cdot 4 \mathrm{H}_{2} \mathrm{O}$, where $\mathrm{Al}^{3+}$ is the trivalent cation, and $\mathrm{CO}_{3}{ }^{2-}$ is the anion in the interlayer space. The intercalated anions can be exchanged with other anions available in the environment, a property that is exploited in different areas, from catalysis to medicine [8-11]. The application to corrosion control relies on the LDH capacity to capture aggressive anions from the environment (e.g., chloride ions) [12], while releasing anionic inhibiting species to maintain charge neutrality [13]. LDHs can be used as additives incorporated into organic coatings [14] or as a conversion film directly grown on the metallic substrates [15].

Studies of the action of LDH in concrete are also available in the literature. In 2003, a paper was published reporting the use of a synthetic nitrite type of hydrocalumite (CaAl-LDH) to counteract the chloride penetration in concrete through a so called suppressing salt injury (SSI) method [16]. The LDH was added to the concrete as chloride absorbent. The process involved the ionic exchange with nitrite ion (corrosion inhibitor) that was released to the environment. Still today, this remains the main concept behind the anticorrosion action of LDH in reinforced concrete. Concrete with this LDH was used for repairing a viaduct pier and a platform abutment. One year later, in 2004, a paper reported the use of nitrobenzoic acid, naphthalene-2, 6-disulfonic acid, and naphthalene-2 sulfonic acid salts, intercalated in CaAl-LDH, with the aim of controlling the kinetics of cement hydration by programming the temporal release of those compounds [17]. The use of LDH to control the cement hydration kinetics has been studied by several groups [18-21]. However, most of the work with LDH in concrete is dedicated to the mitigation of steel rebars corrosion, either in chloride media [22-40] or carbonated concrete [32,41-48]. Many studies have been done in simulated concrete pore solution [35,38,43,46], just a few in mortar [31,43] and only one in concrete [16]. Often, the workability and mechanical properties of mortar and concrete with LDH are also characterized [18-22,28,37,41]. Recent reports 
describe the use of LDH as an anti-corrosive pigment in epoxy coatings for steel rebars [49] and a field evaluation of LDH effect on the aging resistance of asphalt concrete after four years of road service [50].

In the above-mentioned studies, the intercalated anions were nitrite (corrosion inhibitor), nitrate, carbonate, and chloride. The most commonly studied LDH is by far MgAl-LDH [20-22,24,27,32, 35,37-39,41-47,49,50], followed by CaAl [16-18,26,32-34,40], hydrotalcite [23,29,36], and modified hydrotalcite $[25,28,31]$. ZnAl-LDH is a new composition that has been studied in only two papers [51,52]. One has analyzed the $\mathrm{LDH}$ ability to capture chloride and release nitrite in $\mathrm{NaCl}$ solutions of different concentrations and characterized the corrosion protection in saturated $\mathrm{Ca}(\mathrm{OH})_{2}$ solution after the addition of LDH. The other paper has presented three $\mathrm{ZnAl}$-phthalate LDHs prepared by different methods and compared their effect on the corrosion resistance of steel in saturated $\mathrm{Ca}(\mathrm{OH})_{2}$ solution adjusted to $\mathrm{pH}=11$.

This work aims at extending the current knowledge on the action of $\mathrm{ZnAl}-\mathrm{LDH}$ in cementitious materials by investigating the behavior of the LDH in aqueous solution, in cement paste, and in mortar. The analyzed parameters were the stability of LDH in aqueous solutions of different $\mathrm{pH}$, the capacity of $\mathrm{ZnAl}-\mathrm{LDH}$ for capturing chloride ions in solutions of different chloride concentration and $\mathrm{pH}$, the effect on the corrosion of steel in aqueous solution, the influence on the curing of cement paste, and the impact on the corrosion of steel rebar embedded in mortar.

\section{Materials and Methods}

\subsection{Synthesis of $\mathrm{ZnAl}-\mathrm{NO}_{3}$ and $\mathrm{ZnAl}-\mathrm{NO}_{2} \mathrm{LDHs}$}

The LDH materials studied in this work were produced by Smallmatek, Lda (Aveiro, Portugal) and prepared according to their own production procedures. Briefly, $0.5 \mathrm{M} \mathrm{Zn}\left(\mathrm{NO}_{3}\right)_{2} \cdot 6 \mathrm{H}_{2} \mathrm{O}$ and $0.25 \mathrm{M}$ $\mathrm{Al}\left(\mathrm{NO}_{3}\right)_{3} \cdot 9 \mathrm{H}_{2} \mathrm{O}$ were slowly added to $1.5 \mathrm{M} \mathrm{NaNO}_{3}$ or $\mathrm{NaNO}_{2}$ solution under vigorous stirring at room temperature. During this reaction, the $\mathrm{pH}$ was kept constant $(\mathrm{pH}=10 \pm 0.5)$ by the addition of $2 \mathrm{M} \mathrm{NaOH}$ solution. The production process was carried out in a custom-made stainless-steel pilot-scale reactor (BTL-Indústrias Metalúrgicas, S.A., Oliveira de Azeméis, Portugal) equipped with a PID (proportional-integral-derivative) controller, which allowed the automatic control and correction of important process parameters (e.g., $\mathrm{pH}$ and temperature), and peristaltic pumps for precise addition of chemicals. The obtained slurry was washed with deionized water and filtered under reduced pressure, followed by drying using an industrial spray dryer to guarantee uniform and fine powders. The powders were finally separated in different size fractions using a vibratory sieve shaker (Retsch, Haan, Germany).

\subsection{Structure and Morphology of the ZnAl LDH}

Scanning electron microscopy (SEM) was performed on Hitachi (Tokyo, Japan) S-4100 field emission electron microscope with an accelerating voltage of $25 \mathrm{kV}$. X-ray diffractograms (XRD) were acquired using a PANalytical X'Pert MPD PRO diffractometer (Almelo, The Netherlands) with Bragg-Brentano geometry, Ni-filtered $\mathrm{CuK} \alpha$ radiation, PIXcel1D detector, and step 0.026 . The exposition corresponded to about $2 \mathrm{~s}$ per step over the angular range between 3 and 70 . The particle size distribution of the different LDH batches was measured on a LS230 particle sizer (Coulter Corporation, Miami, FL, USA). Fourier transform infrared spectroscopy (FT-IR) spectra were collected in a Spectrum Two spectrometer (PerkinElmer Inc., Waltham, MA, USA) with a UATR TWO unit (Diamond), 64 scans, $4 \mathrm{~cm}^{-1}$ resolution, in a wavelength range of $400-4000 \mathrm{~cm}^{-1}$.

\subsection{Stability of ZnAl LDH in Aqueous Solution}

The stability of $\mathrm{LDH}$ powders in water in the $\mathrm{pH}$ range from 1 to 14 (adjusted with $\mathrm{HNO}_{3}$ or $\mathrm{KOH}$ ) was evaluated by placing $1 \mathrm{~g}$ of $\mathrm{LDH}$ in $50 \mathrm{~mL}$ of each solution (in intervals of $1 \mathrm{pH}$ unit) for one month. After this period, the remaining powder was weighted (after washing in distilled water and drying). 


\subsection{Ion Exchange in Aqueous Solution}

The capacity of the LDHs for capturing chloride ions was assessed by potentiometry, using a chloride ion-selective electrode (DX235-Cl from Mettler Toledo, Columbus, OH, USA) with a mercury/mercurous sulfate reference electrode (REF621, Radiometer Analytical SAS, Lyon, France) connected to a SevenMulti meter from Mettler Toledo, Columbus, OH, USA. Aqueous $\mathrm{NaCl}$ solutions of various concentrations and $\mathrm{pH}$ were continuously analyzed with the $\mathrm{Cl}^{-}$sensor. After a time for stable reading, $1 \mathrm{~g}$ of $\mathrm{LDH}$ was added to $50 \mathrm{~mL}$ solution under stirring, while the sensor kept measuring.

\subsection{Effect of ZnAl LDH on the Corrosion of Steel in Aqueous Solutions}

Cross-sections of steel rebars with one side electrically connected to the copper wire were mounted in epoxy resin. The other side was ground down to $\mathrm{SiC} 4000$ grade and covered with insulating tape (Electroplating Tape 470M, 3M, Saint Paul, MN, USA) with a circular opening of $0.24 \mathrm{~cm}^{2}$, to provide a constant area of analysis for all measurements and to limit the risk of crevice corrosion in the experiments. The corrosion was analyzed by electrochemical impedance spectroscopy (EIS) using IVIUM CompactStat (Ivium Technologies, Eindhoven, The Netherlands) or Autolab PGSTAT204 (Metrohm Autolab, Utrecht, The Netherlands) potentiostats, in a tree-electrode arrangement, with the steel sample as working electrode, a saturated calomel electrode (SCE) as a reference, and a platinum counter electrode. The samples were immersed in $0.05 \mathrm{M} \mathrm{NaCl}(\mathrm{pH}=5.8)$ or $0.05 \mathrm{M} \mathrm{NaCl}+0.1 \mathrm{M}$ $\mathrm{KOH}(\mathrm{pH}=13)$, with and without $\mathrm{LDH}(0.5 \%$ mass/volume), and the corrosion monitored over time, with EIS spectra acquired at open circuit potential (OCP) with a sine wave perturbation of $12 \mathrm{mV} r \mathrm{rs}$, from $10^{5}$ to $10^{-3} \mathrm{~Hz}$ with 10 points per decade with logarithmic distribution.

\subsection{Cement Pastes and Mortars Preparation}

Cement pastes with different LDH additions were prepared with CEM II/B-L $32.5 \mathrm{~N}$ cement and distilled water ( 0.5 water/cement ratio). The specimens were cubes with $2.5 \mathrm{~cm}$ edges. The same cement and water, together with $0-2 \mathrm{~mm}$ size siliceous sand, were used to prepare mortars (14.5 wt.\% cement $+13 \mathrm{wt} . \%$ water $+72.5 \mathrm{wt} . \%$ sand). The water/cement ratio was 0.9 , a value selected to warrant high porosity and faster corrosion of steel. The quantity of LDH added to the mortars was $0.3 \%$ of their total mass (corresponding to $2 \%$ of the mass of cement). The size of the mortars was $7 \times 4 \times 4 \mathrm{~cm}^{3}$, and a non-corrugated steel bar of $8 \mathrm{~mm}$ diameter was placed in the middle (nominal composition of steel (\%): $\mathrm{Fe}, 98.08 ; \mathrm{C}, 0.20 ; \mathrm{Mn}, 0.70 ; \mathrm{Cu}, 0.40 ; \mathrm{Si}, 0.20 ; \mathrm{Cr}, 0.20 ; \mathrm{Ni}, 0.10 ; \mathrm{S}, 0.05 ; \mathrm{P}, 0.02 ; \mathrm{Mo}, 0.02 ; \mathrm{V}, 0.02$; $\mathrm{N}, 0.01$ ). Prior to the embedment in the mortars, the steel bars were etched in $\mathrm{HCl}$ aqueous solution (50 vol.\%), abraded with $\mathrm{SiC}$ paper down to 1200 grade, and passivated in $0.1 \mathrm{M} \mathrm{KOH}$ solution for $3 \mathrm{~h}$. The area of steel bar inside the mortar was $12.25 \mathrm{~cm}^{2}$. After $24 \mathrm{~h}$ in the mold, the mortars were left curing for 8 days immersed in water. This time was sufficient for mechanical integrity and short enough to warrant fast degradation.

\subsection{Chloride Sensors inside Mortars}

$\mathrm{Ag} \mid \mathrm{AgCl}$ potentiometric sensors were placed inside mortars for the direct measurement of chloride ingress. The sensors were produced on $1 \mathrm{~mm}$ diameter $\mathrm{Ag}$ wires embedded in epoxy. The silver chloride layer was formed at the polished Ag surface by applying a constant current of $2 \mathrm{~mA} / \mathrm{cm}^{2}$ in $0.1 \mathrm{M} \mathrm{HCl}$ for $30 \mathrm{~min}$. The sensors were placed at $0.5,1$, and $1.5 \mathrm{~cm}$ from the surface of the mortar samples. After 28 days of curing the mortars were immersed in $3.5 \% \mathrm{NaCl}$ solution. The potential was measured with respect to a saturated calomel electrode located in the external $\mathrm{NaCl}$ solution, using a CompactStat potentiostat connected to a peripheral differential amplifier (both from Ivium Technologies, Eindhoven, The Netherlands) for simultaneous measurements. 


\subsection{Impact of ZnAl LDH on the Corrosion of Steel Rebars in Mortars}

Mortars with steel bars were immersed in 3.5\% NaCl solution, and impedance measurements were performed in the same conditions described in 2.5, except for the smaller number of points per decade (5 points) to save measurement time due to the larger number of samples to test.

\section{Results and Discussion}

\subsection{Structure and Morphology of the Synthesized ZnAl LDHs}

$\mathrm{ZnAl}-\mathrm{NO}_{3}$ and $\mathrm{ZnAl}-\mathrm{NO}_{2}$ powders of different particle sizes were studied in this work. Figure $1 \mathrm{a}-\mathrm{d}$ show SEM images of the different batches. In all cases, it was possible to identify the lamellar shape typical of LDH materials. The particle size distribution is presented in Figure 1e and reveals two batches of particles in the range of $25 \mu \mathrm{m}$ (slightly smaller for $\mathrm{ZnAl}-\mathrm{NO}_{3}$ ), both with a small fraction around $0.5 \mu \mathrm{m}$, and two batches of particles above $125 \mu \mathrm{m}$, with mean values, centered on $650 \mu \mathrm{m}$ for $\mathrm{ZnAl}-\mathrm{NO}_{2}$ and $450 \mu \mathrm{m}$ for $\mathrm{ZnAl}-\mathrm{NO}_{3}$. Figure $1 \mathrm{f}$ depicts the XRD patterns of the LDH powders. The $X$-ray diffraction data showed the same LDH phase regardless of the particle size.

The diffractograms of $\mathrm{ZnAl}-\mathrm{NO}_{3}$ of different particle size practically overlapped and showed the characteristic (003), (006), (110), and (113) reflections occurring, respectively, at $10^{\circ}, 20^{\circ}, 60.5^{\circ}$, and $61.5^{\circ}$, confirming the formation of $\mathrm{LDH}$ intercalated with $\mathrm{NO}_{3}{ }^{-}$[13]. On $\mathrm{ZnAl}-\mathrm{NO}_{2}$, the peaks shifted to higher angles, which was indicative of the intercalation of smaller anions. The (003), (006), (110), and (113) reflections now occurred around, respectively, $11.6^{\circ}, 23^{\circ}, 60.2^{\circ}$, and $61.5^{\circ}$, values similar to those found with a similar $\mathrm{ZnAl}-\mathrm{NO}_{2}$ [51] and other $\mathrm{LDHs}$ with $\mathrm{NO}_{2}^{-}$in the interlayer space $[31,35,43]$.

FTIR analysis was used to further confirm the presence of nitrate and nitrite ions in the LDH structures-Figure 2. The characteristic bands of LDH were visible in both spectra, namely, a broad band around $3400 \mathrm{~cm}^{-1}$ corresponding to stretching vibrations of the hydroxyl groups of both layer hydroxide moieties and interlayer water, a band at $1660 \mathrm{~cm}^{-1}$ due to the deformation vibration mode of $\mathrm{OH}$ bonds in water molecules, and bands at $1000-600 \mathrm{~cm}^{-1}$ assigned to the metal-hydroxide group connection (M-OH) and at 600-400 $\mathrm{cm}^{-1}$ ascribed to the metal-oxygen link (M-O) [53]. The main differences between $\mathrm{ZnAl}-\mathrm{NO}_{3}$ and $\mathrm{ZnAl}-\mathrm{NO}_{2}$ relied on the $\mathrm{N}-\mathrm{O}$ vibration modes, being a single stretching band at $1346 \mathrm{~cm}^{-1}$ for nitrate and two bands at 1358 and $1244 \mathrm{~cm}^{-1}$ for nitrite, related to the symmetric and asymmetric stretching.

\subsection{Stability of ZnAl LDH in Aqueous Solution}

The stability of this type of material in aqueous solution has great practical importance. In order to encompass all possible applications, the stability of the LDHs was studied in the full $\mathrm{pH}$ range. Naturally, for applications in concrete, it is the alkaline region that matters because the typical $\mathrm{pH}$ of cement paste, mortar, or concrete ranges from 12.5 (fresh) to 13.5 (cured) [2-4]. Figure 3 shows the amount of $\mathrm{LDH}$ that remained after 1 month in contact with water in the pH range from 1 to 14 . The results indicated that $\mathrm{ZnAl-LDH}$ was unstable at extreme $\mathrm{pH}$ values, either in acidic or alkaline conditions. It dissolved completely in $\mathrm{pH}=1$, while in $\mathrm{pH}=2$ only $20 \%$ of solid remained. In a solution with $\mathrm{pH}=13$, around $40 \%$ of the sample was dissolved, whereas in a solution with $\mathrm{pH}=14$ just $20 \%$ of powder remained. This dissolution in the high alkaline region suggested that the same was likely to occur in cementitious environments, which could be critical for the application of these LDHs in concrete. In the $\mathrm{pH}$ range from 3 to 12 , the $\mathrm{LDH}$ was less affected, though around $10 \%$ of $\mathrm{ZnAl}-\mathrm{NO}_{2}$ and $20 \%$ of $\mathrm{ZnAl}-\mathrm{NO}_{3}$ tended to dissolve, according to Figure 3. The dissolution at mild pH values has been discussed in a previous work by Galvão et al. [54]. 

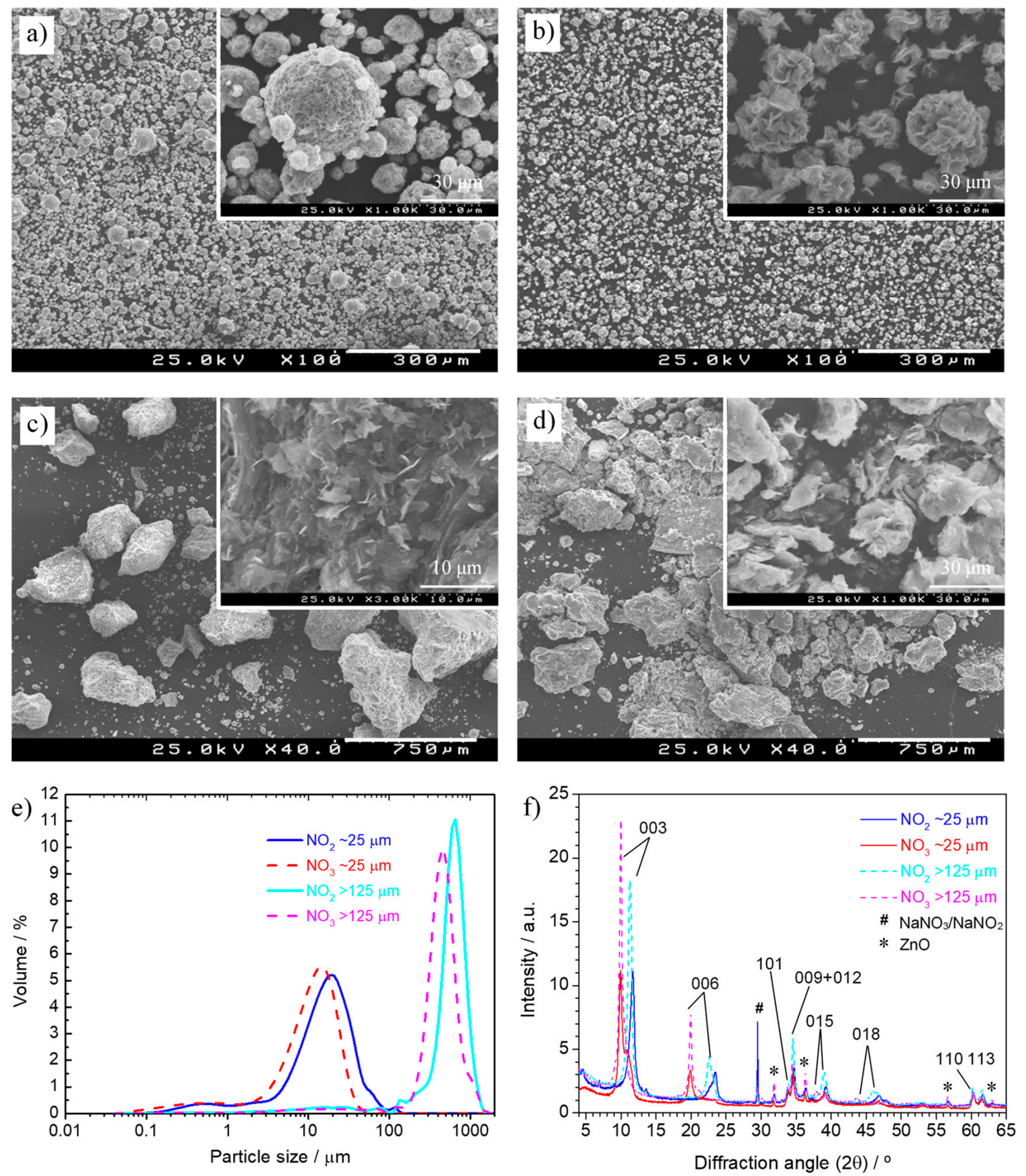

Figure 1. Scanning electron microscopy (SEM) images of (a) $\mathrm{ZnAl}-\mathrm{NO}_{2}$ with mean particle size $25 \mu \mathrm{m}$, (b) $\mathrm{ZnAl}-\mathrm{NO}_{3}$ with mean particle size $\sim 25 \mu \mathrm{m}$, (c) $\mathrm{ZnAl}-\mathrm{NO}_{2}$ with particle size $>125 \mu \mathrm{m}$, (d) $\mathrm{ZnAl}-\mathrm{NO}_{3}$ with mean particle size $>125 \mu \mathrm{m}$; (e) particle size distribution of the layered double hydroxide (LDH) powders; (f) XRD diffractograms of the four LDH powders. 


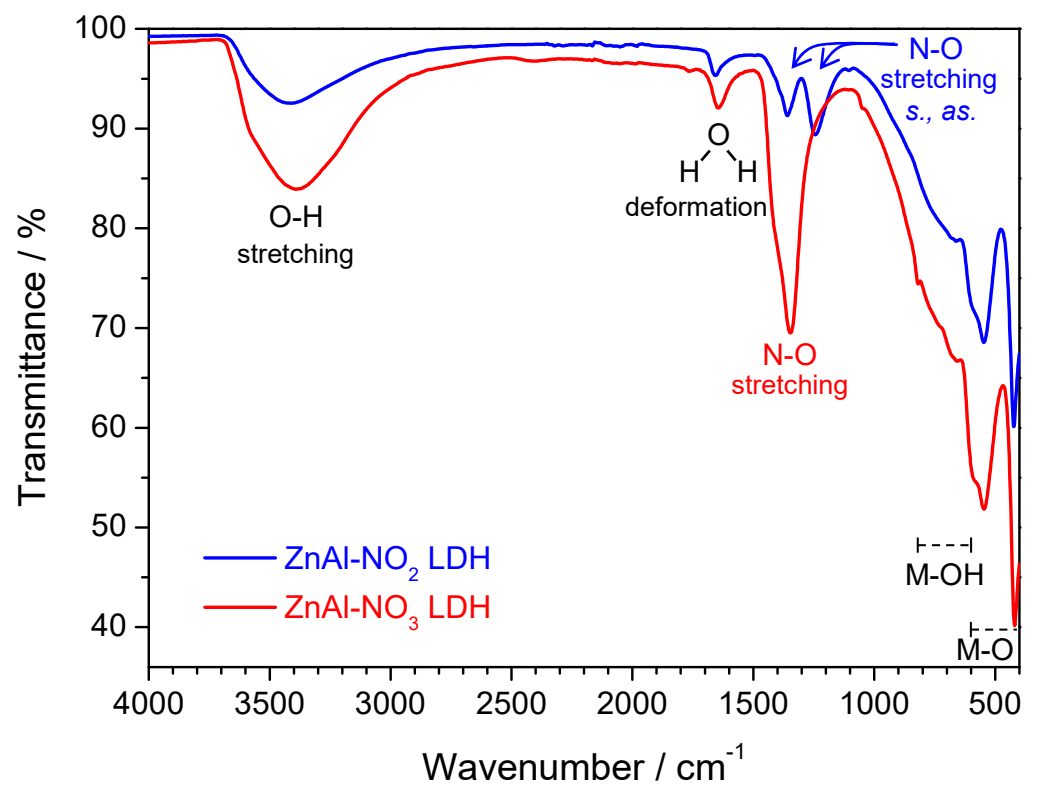

Figure 2. FTIR spectra of $\mathrm{ZnAl}-\mathrm{NO}_{3}$ and $\mathrm{ZnAl}-\mathrm{NO}_{2}$.

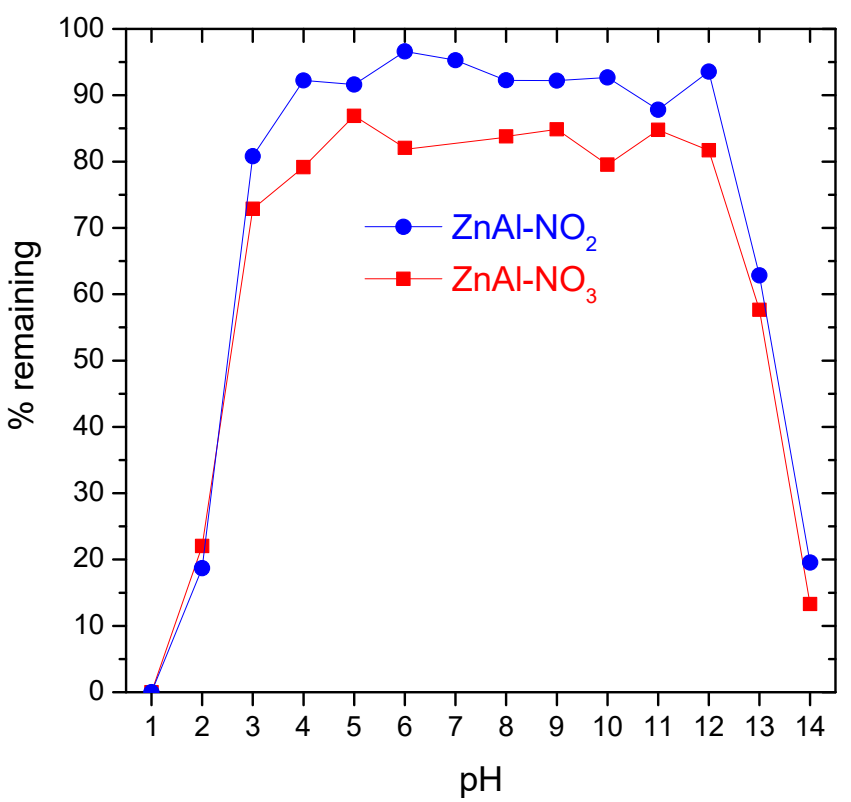

Figure 3. Mass (\%) of undissolved LDH powder after 1 month of immersion in water in the $\mathrm{pH}$ range 1 to 14 .

\subsection{The Capacity of ZnAl LDH for Capturing Chloride Ions}

One of the key properties for the use of LDHs in corrosion control is the capacity to capture aggressive species, namely, chloride ions. Figure 4a shows the decrease in chloride concentration of $\mathrm{NaCl}$ solutions after the addition of LDH. The process was fast, occurring in the first minutes after the addition of the powder to the solution, and led to a significant capture of chloride ions. However, the ability to capture chloride decreased with the increase in $\mathrm{pH}$ and was completely lost at $\mathrm{pH} 13$. The decrease in the ability to capture chloride ions at high $\mathrm{pH}$ was attributed to two factors. The first, based on Figure 3, was the partial dissolution of the $\mathrm{LDH}$ at high $\mathrm{pH}$, leading to a smaller amount of material with capture ability. The second was the higher tendency for the ZnAl-LDH to exchange with $\mathrm{OH}^{-}$ions instead of $\mathrm{Cl}^{-}$ions, an evidence based on the results of Figure 4 and a behavior similar to other LDHs [55]. The results obtained in this work point to the following order of anion selectivity: 
$\mathrm{NO}_{3}{ }^{-}<\mathrm{NO}_{2}{ }^{-}<\mathrm{Cl}^{-}<\mathrm{OH}^{-}$. Ions to the right enter the $\mathrm{LDH}$ preferentially, and, once inside, they are hardly displaced by those on the left.

a)

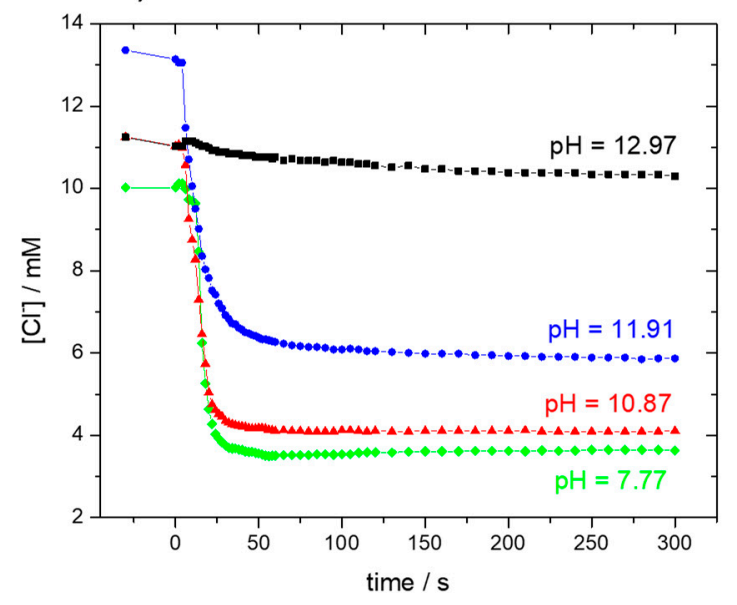

b)

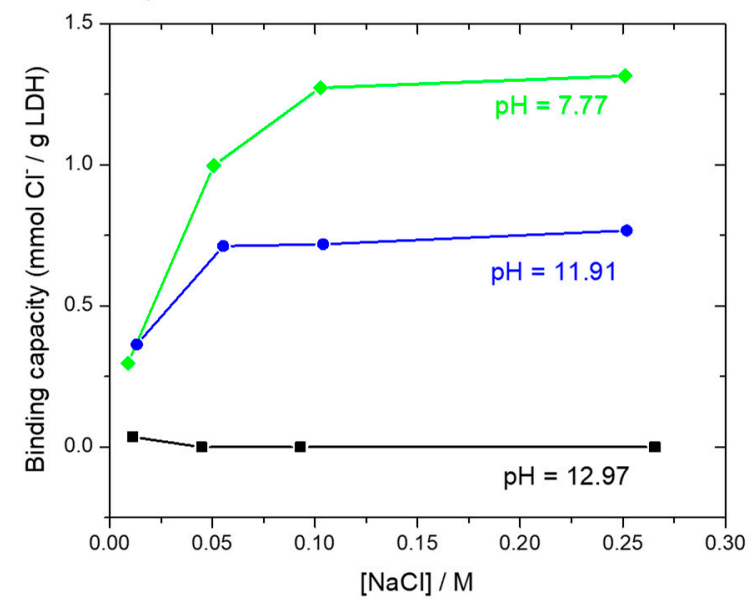

Figure 4. (a) Decrease of chloride concentration of $0.01 \mathrm{M} \mathrm{NaCl}$ solution at different $\mathrm{pH}$ after the addition of $\mathrm{ZnAl}-\mathrm{NO}_{2}$ (solution volume $=50 \mathrm{~mL}, 1 \mathrm{~g}$ of $\mathrm{LDH}$ added at time $\mathrm{t}=0$ ); (b) Chloride binding capacity of $\mathrm{ZnAl}-\mathrm{NO}_{2}$ at different $\mathrm{pH}$ and chloride concentrations.

The effect of both chloride concentration and $\mathrm{pH}$ on the amount of chloride captured by $\mathrm{ZnAl}-\mathrm{LDH}$ can be easily perceived in Figure $4 \mathrm{~b}$, which was determined using $\mathrm{ZnAl}-\mathrm{NO}_{2} \mathrm{LDH}$. This figure presents the chloride binding capacity $B_{c}$, defined as the amount of chloride that is bound (captured) by a given mass of $\mathrm{LDH}$, and calculated using the following equation $[46,56]$ :

$$
B_{c}=\frac{V_{s o l}\left(C_{0}-C_{e}\right)}{m_{L D H}}
$$

where $B_{c}$ is the binding capacity $\left(\operatorname{moles}_{\mathrm{Cl}} / \mathrm{g}_{\mathrm{LDH}}\right), V_{\text {sol }}$ is the volume of solution $\left(\mathrm{dm}^{3}\right), m_{\mathrm{LDH}}$ is the mass of LDH added to the solution (g), and $C_{0}$ and $C_{e}$ are, respectively, the initial and equilibrium chloride concentrations $\left(\mathrm{mol} \mathrm{dm}{ }^{-3}\right)$. The binding capacity increased with chloride concentration until a value where it remained constant. The maximum value, $B_{c}=1.25 \mathrm{mmol}_{\mathrm{Cl}} / g_{\mathrm{LDH}}$, was measured in near-neutral solution and for $\left[\mathrm{Cl}^{-}\right]>0.1 \mathrm{M}$. In agreement with Figure $4 \mathrm{a}$, the binding capacity was strongly dependent on the $\mathrm{pH}$, decreasing with it, and becoming zero at $\mathrm{pH} 13$. This result is of utmost importance for applications in concrete.

\subsection{Effect of $\mathrm{ZnAl} \mathrm{LDH}$ on the Corrosion of Steel in Aqueous Solution}

To simulate the ability of ZnAl-LDH to control the corrosion of steel in the concrete environment, steel samples were immersed in $0.05 \mathrm{M} \mathrm{NaCl}$ solutions with $\mathrm{pH}=13(\sim 0.1 \mathrm{M} \mathrm{KOH})$ with and without 0.5 wt. $\% \mathrm{ZnAl}-\mathrm{NO}_{2}$. The $\mathrm{NaCl}$ concentration and the amount of $\mathrm{LDH}$ in solution were chosen to be similar to past works [13]. Bode plots of the impedance of the steel measured during the time of immersion are presented in Figure 5a (control, without LDH) and Figure $5 b$ (with $0.5 \%$ LDH). Similar EIS spectra were obtained for these systems, namely, high impedance values at intermediate and low frequencies, which tended to increase with time of immersion. Moreover, two time constants were detected, one at higher frequencies, attributed to the passive film formed under alkaline conditions, and another at low frequencies $\left(\sim 10^{-2} \mathrm{~Hz}\right)$ ascribed to small active areas of steel coincident with pores and defects in the passive film. With time, these pores and defects decreased in size and number (due to the passivating effect of the alkaline environment and the presence of inhibitors), which explains the increase in impedance with time. 
a)

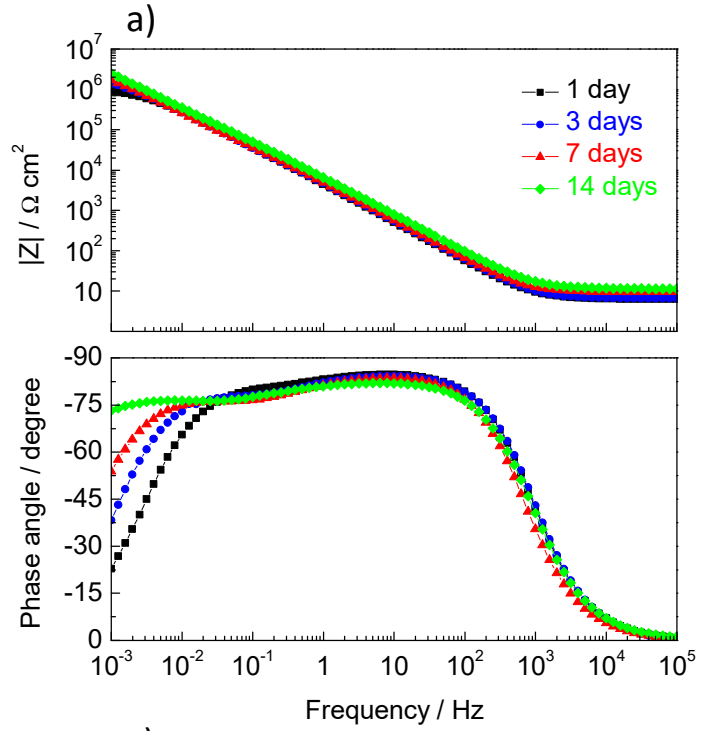

c)
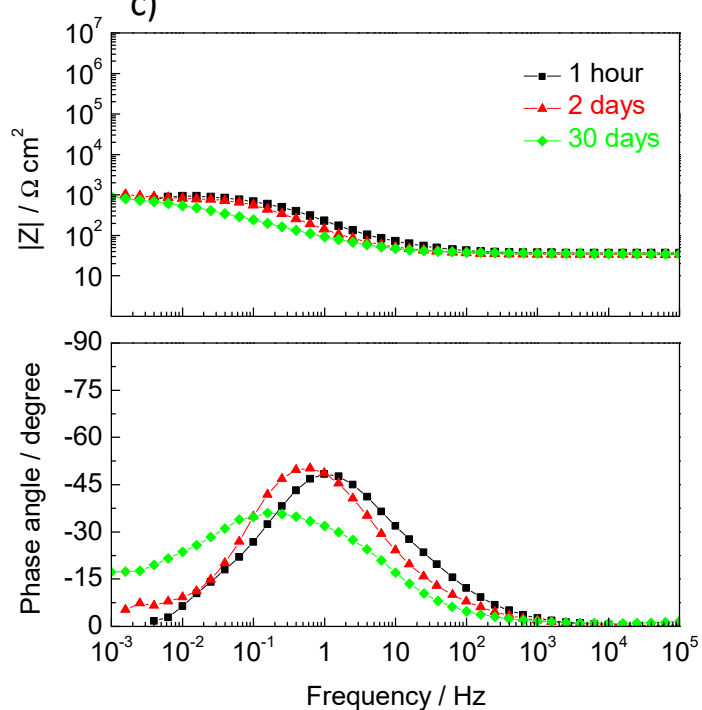

e)
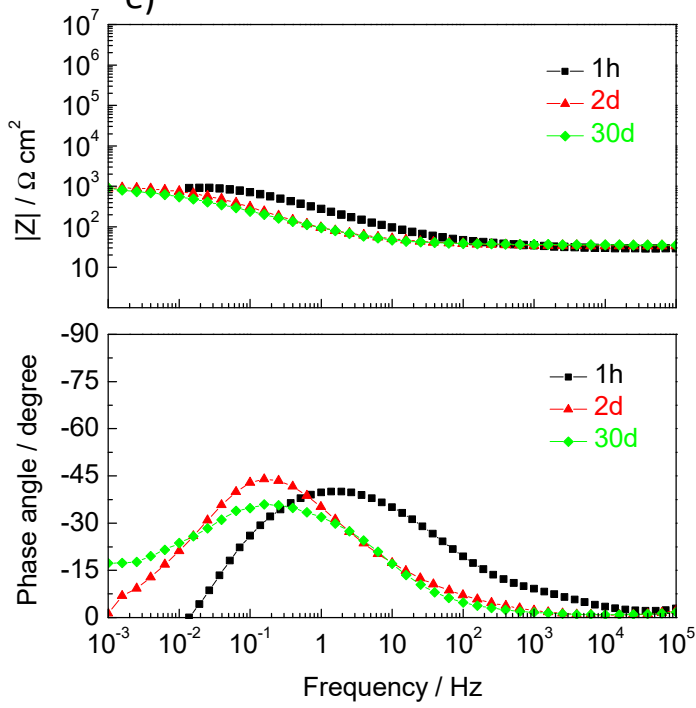

b)
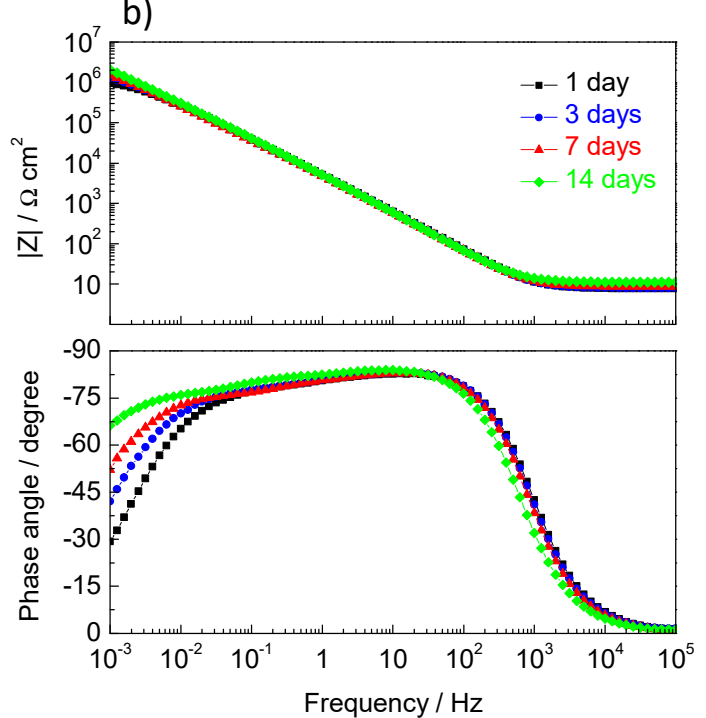

d)
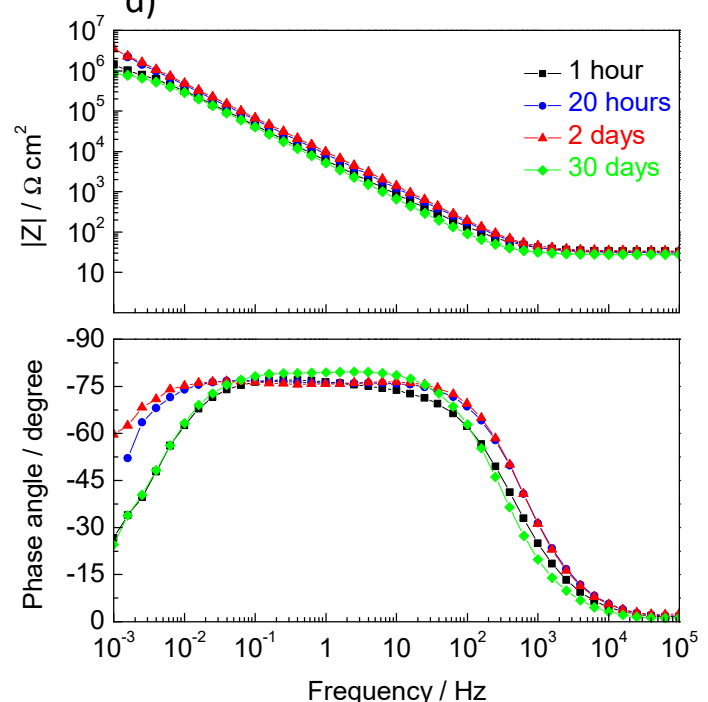

f)



Figure 5. EIS spectra of steel obtained during immersion in (a) $0.05 \mathrm{M} \mathrm{NaCl}(\mathrm{pH}=13)$, (b) $0.05 \mathrm{M} \mathrm{NaCl}$ $(\mathrm{pH}=13)+0.5 \% \mathrm{ZnAl}-\mathrm{NO}_{2}$, (c) $0.05 \mathrm{M} \mathrm{NaCl}(\mathrm{pH}$ ) $)$, (d) $0.05 \mathrm{M} \mathrm{NaCl}+0.5 \% \mathrm{ZnAl}-\mathrm{NO}_{2}$, (e) $0.05 \mathrm{M}$ $\mathrm{NaCl}+0.5 \% \mathrm{ZnAl}-\mathrm{NO}_{3}$, (f) equivalent electric circuits used for describing the impedance response. 
Since the reference system presented already high impedance, the effect of the LDH could not be easily identified. The effect became evident in $0.05 \mathrm{M} \mathrm{NaCl}$ solution without $\mathrm{pH}$ adjustment ( $\mathrm{pH} \sim 6$ ). This slightly acidic $\mathrm{pH}$ was due to the hydrolysis of dissolved $\mathrm{CO}_{2}$ from the atmosphere $[57,58]$. The corrosion of steel, in this solution, was fast with impedance at low frequencies around $1 \mathrm{k} \Omega \mathrm{cm}^{2}$ (Figure 5c). The addition of $0.5 \% \mathrm{ZnAl}-\mathrm{NO}_{2} \mathrm{LDH}$ led to passivation of the steel sample, with a considerable increase in impedance and the typical capacitive behavior of passive metals (Figure $5 \mathrm{~d}$ ). Indeed, at the end of the test (1 month), the surface was still intact and shiny. Two effects might have contributed to this result: the capture of chloride ions from the solution and the release of nitrite ions in an amount enough to act as a corrosion inhibitor. The addition of a similar quantity of $\mathrm{ZnAl}-\mathrm{NO}_{3}$ to $0.05 \mathrm{M} \mathrm{NaCl}$ did not produce any significant change, being the impedance response (Figure 5e) similar to that of the blank solution (Figure $5 \mathrm{c}$ ). This means that the amount of captured chloride was not that significant compared to the quantity of chloride ions still remaining in solution. These results lead to the conclusion that the key factor for the action of LDH in the present conditions is the release of nitrite ions to the solution.

The impedance responses were numerically fitted with the Zview software (Version 3.5g, Scribner Associates, Southern Pines, NC, USA) using the equivalent electric circuits of Figure $5 f$. The circuit I served as an analog of the passive surface with the solution resistance $\left(R_{s}\right)$, the capacitance of the passive film $\left(C_{\text {pass }}\right)$, the resistance of the solution inside the pores and defects of the passive film $\left(R_{\text {pass }}\right)$, double layer capacitance $\left(C_{d l}\right)$, and charge transfer resistance $\left(R_{c t}\right) . C_{d l}$ and $R_{c t}$ occurred at the bottom of the pores and defects of the passive film, in the points where the metal was directly exposed to the solution. Circuit II was the analog of the active steel surface with just three elements, $R_{s}, C_{d l}$, and $R_{c t}$. In some cases, this simple circuit can be more complicated, with the appearance of the response of a deposit of corrosion products at higher frequencies and/or the manifestation of diffusion control at lower frequencies.

In the fitting procedure, constant phase elements (CPE) were used instead of capacitances, to account for the non-ideal capacitive behavior of the surface arising from the heterogeneities and uneven reactivity on the electrode surface [59]. The CPE values were converted to capacitances using the equation proposed by Brug et al. [60],

$$
C=\sqrt[n]{Y_{0}}\left(\frac{1}{R_{1}}+\frac{1}{R_{2}}\right)^{\frac{n-1}{n}}
$$

where $Y_{0}$ and $n$ are, respectively, the frequency-independent admittance and the power of the CPE, and $R_{1}$ and $R_{2}$ are the resistances in series and in parallel with the CPE, respectively.

The parameters from the fitting analysis and application of Equation (2) are presented in Table 1. The evolution of the parameters was in line with the qualitative description presented above. At high $\mathrm{pH}$, the impedance of steel was high and increased with time, particularly by the increase of $R_{\text {pass }}$ and $R_{c t}$. The capacitances $C_{\text {pass }}$ and $C_{d l}$ did not change significantly. The effect of nitrite at high $\mathrm{pH}$ was manifested mainly by a slightly higher $R_{c t}$ and a lower $C_{d l}$ compared to the blank solution. The effect of nitrite was visible in near-neutral $\mathrm{pH}$, where the impedance was 3 orders of magnitude higher than the non-inhibited $\mathrm{NaCl}$ solution, mainly due to the high $R_{c t}$, which was in the same order as the samples in alkaline solution. The parameter values of steel in $\mathrm{NaCl}$ solution with or without $\mathrm{ZnAl}-\mathrm{NO}_{3}$ were similar, with high capacitances and low resistances, particularly $R_{c t}$. The fitting in the case of $\mathrm{ZnAl}-\mathrm{NO}_{3}$ needed to consider a time constant at higher frequencies attributed to a surface layer, either a reminiscence of the weak native passive film or the formation of a layer of corrosion products. These results showed the ability of $\mathrm{ZnAl}-\mathrm{NO}_{2}$ to significantly increase the corrosion resistance of steel. No effect was found for $\mathrm{ZnAl}-\mathrm{NO}_{3}$. 
Table 1. Parameters determined by numerical fitting of the EIS spectra shown in Figure 5 with capacitances calculated using Equation (2).

\begin{tabular}{|c|c|c|c|c|c|c|c|c|c|c|c|c|}
\hline $\mathrm{pH}$ & Composition & Time & $\begin{array}{c}R_{s} \\
\left(\Omega \mathrm{cm}^{2}\right)\end{array}$ & $\begin{array}{c}Y_{0, p a s s} \\
\left(\mathrm{~F} \mathrm{~cm}^{-2} \mathrm{~s}^{\mathrm{n}-1}\right)\end{array}$ & $\mathbf{n}_{\text {pass }}$ & $\begin{array}{c}C_{\text {pass }} \\
\left(\mu \mathrm{F} \mathrm{cm}^{-2}\right)\end{array}$ & $\begin{array}{c}R_{\text {pass }} \\
\left(\Omega \mathrm{cm}^{2}\right)\end{array}$ & $\begin{array}{c}Y_{0, d l} \\
\left(\mathrm{~F} \mathrm{~cm}^{-2} \mathrm{~s}^{\mathrm{n}-1}\right)\end{array}$ & $n_{d l}$ & $\begin{array}{c}C_{d l} \\
\left(\mu \mathrm{F} \mathrm{cm}^{-2}\right)\end{array}$ & $\begin{array}{c}R_{c t} \\
\left(\Omega \mathrm{cm}^{2}\right)\end{array}$ & $X^{2} / 10^{-4}$ \\
\hline \multirow{8}{*}{13} & \multirow{4}{*}{ Blank } & $1 d$ & 6.7 & $3.07 \times 10^{-5}$ & 0.968 & 23.1 & 50.53 & $6.86 \times 10^{-6}$ & 0.701 & 0.23 & $1.09 \times 10^{6}$ & 0.83 \\
\hline & & $3 \mathrm{~d}$ & 6.9 & $3.55 \times 10^{-5}$ & 0.946 & 22.1 & 80200 & $9.44 \times 10^{-6}$ & 0.794 & 8.69 & $2.00 \times 10^{6}$ & 0.37 \\
\hline & & $7 \mathrm{~d}$ & 9.8 & $3.45 \times 10^{-5}$ & 0.917 & 16.7 & 81882 & $1.14 \times 10^{-5}$ & 0.793 & 11.1 & $3.87 \times 10^{6}$ & 0.36 \\
\hline & & $14 d$ & 11.7 & $2.76 \times 10^{-5}$ & 0.921 & 13.8 & 220140 & $5.95 \times 10^{-6}$ & 0.740 & 6.52 & $4.27 \times 10^{7}$ & 0.27 \\
\hline & \multirow{4}{*}{$\begin{array}{c}0.5 \% \\
\text { LDH-NO }\end{array}$} & $1 \mathrm{~d}$ & 8.0 & $3.17 \times 10^{-5}$ & 0.945 & 19.6 & 19353 & $8.37 \times 10^{-6}$ & 0.680 & 3.53 & $1.34 \times 10^{6}$ & 0.13 \\
\hline & & $3 d$ & 8.2 & $3.16 \times 10^{-5}$ & 0.950 & 20.4 & 19250 & $8.91 \times 10^{-6}$ & 0.676 & 3.81 & $2.47 \times 10^{6}$ & 0.25 \\
\hline & & $7 \mathrm{~d}$ & 8.9 & $3.29 \times 10^{-5}$ & 0.947 & 20.9 & 28134 & $1.03 \times 10^{-5}$ & 0.701 & 6.02 & $3.98 \times 10^{6}$ & 0.39 \\
\hline & & $14 \mathrm{~d}$ & 11.3 & $3.24 \times 10^{-5}$ & 0.950 & 21.4 & 54358 & $6.03 \times 10^{-6}$ & 0.650 & 3.32 & $1.80 \times 10^{7}$ & 0.34 \\
\hline \multirow{10}{*}{6} & \multirow{3}{*}{ Blank } & $1 \mathrm{~h}$ & 37.3 & - & - & - & - & $1.11 \times 10^{-3}$ & 0.708 & 294 & 1049 & 3.9 \\
\hline & & $2 d$ & 35.5 & - & - & - & - & $1.84 \times 10^{-3}$ & 0.750 & 730 & 938 & 8.8 \\
\hline & & $30 \mathrm{~d}$ & 38.0 & - & - & - & - & $4.00 \times 10^{-3}$ & 0.600 & 1085 & 500 & 10 \\
\hline & \multirow{4}{*}{$\begin{array}{c}0.5 \% \\
\mathrm{LDH}-\mathrm{NO}_{2}\end{array}$} & $1 \mathrm{~h}$ & 33.4 & $2.93 \times 10^{-5}$ & 0.867 & 10.1 & 5063 & $3.46 \times 10^{-6}$ & 0.925 & 2.50 & $1.21 \times 10^{6}$ & 4.2 \\
\hline & & $20 \mathrm{~h}$ & 31.2 & $2.20 \times 10^{-5}$ & 0.870 & 7.41 & 92184 & $2.27 \times 10^{-6}$ & 0.898 & 1.89 & $5.30 \times 10^{6}$ & 3.4 \\
\hline & & $2 d$ & 34.5 & $1.86 \times 10^{-5}$ & 0.878 & 6.70 & 67366 & $3.44 \times 10^{-6}$ & 0.814 & 2.45 & $9.21 \times 10^{6}$ & 1.4 \\
\hline & & $30 \mathrm{~d}$ & 30.0 & $2.50 \times 10^{-5}$ & 0.868 & 8.37 & 9089 & $3.40 \times 10^{-6}$ & 0.915 & 2.46 & $1.30 \times 10^{6}$ & 4 \\
\hline & \multirow{3}{*}{$\begin{array}{c}0.5 \% \\
\mathrm{LDH}-\mathrm{NO}_{3}\end{array}$} & $1 \mathrm{~h}$ & 32.5 & $3.22 \times 10^{-4}$ & 0.645 & 16.2 & 23.5 & $6.82 \times 10^{-4}$ & 0.595 & 40.4 & 1347 & 3 \\
\hline & & $2 d$ & 35.0 & $1.84 \times 10^{-3}$ & 0.681 & 381 & 41.1 & $2.43 \times 10^{-3}$ & 0.733 & 940 & 925 & 1.4 \\
\hline & & $30 d$ & 35.5 & $1.92 \times 10^{-3}$ & 0.680 & 382 & 32 & $2.89 \times 10^{-3}$ & 0.707 & 1063 & 1002 & 8 \\
\hline
\end{tabular}

Note: $Y_{0}$ is the frequency-independent admittance of the CPE; $n$ is the power of the CPE; subscripts pass and $d l$ correspond to passive layer and double layer, respectively; $\chi$ is Chi-squared. 


\subsection{Influence of $\mathrm{ZnAl} \mathrm{LDH}$ on the Hardening of Cement Paste}

After characterizing the LDH powders in aqueous solution, and before the incorporation in a mortar, LDHs were added to cement paste to verify the influence on the curing time. The variables analyzed were the type of $\mathrm{LDH}\left(\mathrm{ZnAl}-\mathrm{NO}_{2}\right.$ or $\left.\mathrm{ZnAl}-\mathrm{NO}_{3}\right)$, the amount added, and the $\mathrm{LDH}$ particle size used. The parameter under analysis was the time needed to demold the specimens prior to the curing stage in water-Figure 6 . A reference sample was typically demolded in $24 \mathrm{~h}$. Upon the addition of ZnAl-LDH, an increase in demolding time was observed. Clearly, the particle size had influence. Too many days were necessary for hardening in the case of $\mathrm{LDH}$ particles with a size of around $25 \mu \mathrm{m}\left(\mathrm{ZnAl}-\mathrm{NO}_{2}\right.$ or $\left.\mathrm{ZnAl}-\mathrm{NO}_{3}\right)$. Furthermore, the hardening time increased significantly as the amount of LDH increased. On the other hand, using LDH particles of larger size (>125 $\mu \mathrm{m})$ allowed for demolding times similar to the reference samples, except for the highest amount tested $(10 \%)$, where the specimens took 7 days to harden before demolding. No differences were found between $\mathrm{ZnAl}-\mathrm{NO}_{2}$ and $\mathrm{ZnAl}-\mathrm{NO}_{3}$.

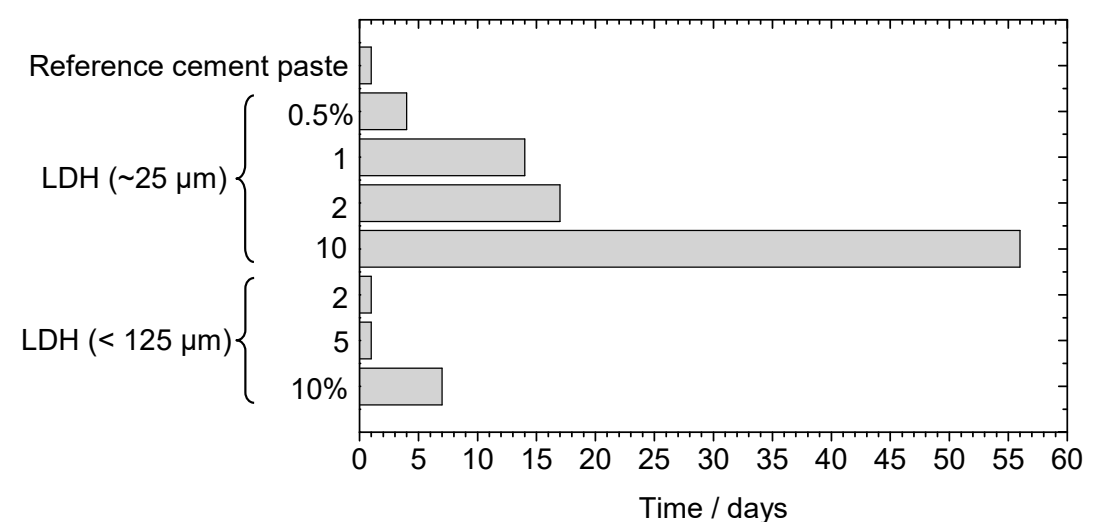

Figure 6. Influence of LDH particle size on the curing time of cement paste (\% of LDH with respect to the mass of cement).

The explanation for the increase in hardening time was attributed to the partial dissolution of LDH, induced by the high $\mathrm{pH}$ of the cement paste, which released zinc ions $\left(\mathrm{Zn}(\mathrm{OH})_{3}{ }^{-}\right.$and $\mathrm{Zn}(\mathrm{OH})_{4}{ }^{2-}$ at high $\mathrm{pH}$ ) that are known to retard cement hydration [61-64]. In the cement pore solution, the presence of zinc ions leads to the formation of a new phase, $\mathrm{Ca}\left(\mathrm{Zn}(\mathrm{OH})_{3}\right)_{2} \cdot 2 \mathrm{H}_{2} \mathrm{O}$ [62-64]. While zinc ions existed in solution, this phase was formed, and the concentrations of $\mathrm{OH}^{-}$and $\mathrm{Ca}^{2+}$ were kept low, preventing the hydration reactions. Only after the depletion of zinc ions, the hydration was able to proceed at a normal rate. In addition, Asavapisit et al. [63] referred that the new $\mathrm{Ca}\left(\mathrm{Zn}(\mathrm{OH})_{3}\right)_{2} \cdot 2 \mathrm{H}_{2} \mathrm{O}$ phase could be deposited over the cement particles, forming a membrane with low permeability, preventing the particles from further hydration reactions.

\subsection{Impact of $\mathrm{ZnAl} \mathrm{LDH}$ on the Corrosion of Steel Rebars in Mortars}

As the last step prior to testing in concrete, experiments were conducted in mortars with sensors to monitor the chloride ingress or with embedded steel rebar for corrosion testing.

\subsubsection{Chloride Sensors inside Mortar}

Figure 7 shows a schematic representation of a mortar sample with embedded sensors immersed in $3.5 \% \mathrm{NaCl}$ aqueous solution and the chloride concentration profiles in a reference mortar (REF) and in a mortar with $0.3 \% \mathrm{ZnAl}-\mathrm{NO}_{2}$ ( $2 \%$ with respect to cement). The chloride concentration inside the mortar was calculated based on the potential readings by the sensor and applying a calibration curve obtained with $\mathrm{NaCl}$ solutions at $\mathrm{pH}=13$. The results showed that chloride was detected first by the sensors closer to the surface and in the reference sample. The sample containing LDH presented lower values of chloride for the same depth and time of exposure compared to the reference sample. This 
means that the addition of LDH was able to slow down the chloride transport in the mortar, in spite of the small amount used ( $0.3 \%$ of total mass) and the high porosity of the mortar. An interesting observation was the peak of chloride concentration occurring not at the surface but a few millimeters inside the mortar. This has been observed many times [65-67] and explained by a difference in composition of the concrete skin (the region closest to the surface) due to the contact with mold walls, segregation of aggregates, and environmental actions, inducing a gradient of moisture along the cover depth [65]. It has also been proposed that surface chemical reactions with the environment change the composition of the outer layer (concrete skin) of the concrete [67].
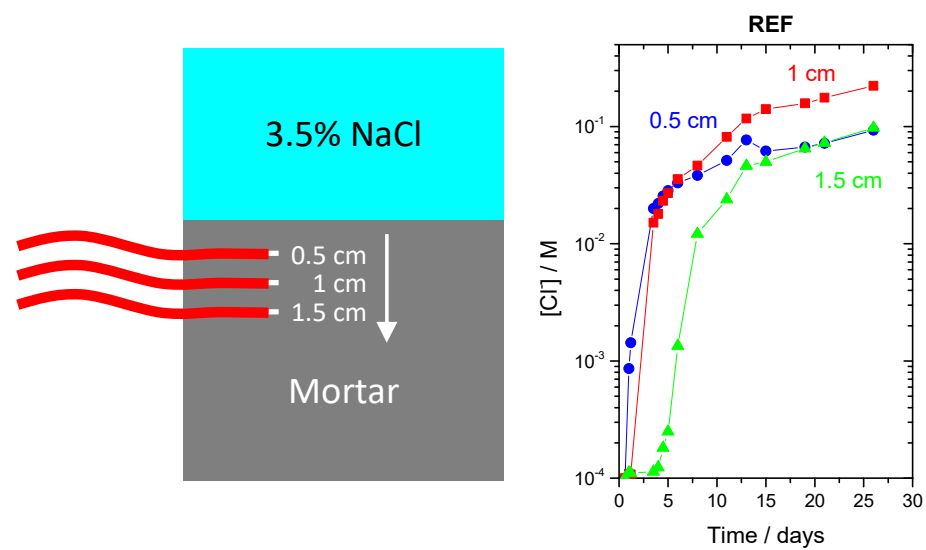



Figure 7. Scheme of mortar with sensors and chloride profiles inside mortar without (REF) and with $\mathrm{ZnAl}-\mathrm{NO}_{2}$.

\subsubsection{Electrochemical Impedance Spectroscopy}

The final tests were performed in steel rebars inside mortars and immersed in $3.5 \% \mathrm{NaCl}$. The samples were monitored by EIS during the immersion time. Bode plots are presented in Figure 8, and Table 2 shows the parameters obtained by the numerical fitting analysis with capacitances calculated by Equation (2). The equivalent electric circuit used was similar to those shown in Figure $5 f$, except that $R_{S}$ is now called $R_{\text {pore }}$ and stands for the resistance of the testing solution in series with the resistance of the solution in the pores structure inside the mortar. Figure 9 depicts the circuit in more detail. The picture showed separately the response in the mortar and the response at the steel interface. The circuit for the response in the mortar was the one proposed for hardened Portland cement paste [68], where $C_{b u l k}$ accounts for the dielectric capacitance associated with the solid phase, $R_{\text {pore }}$ is related to ionic motion in pores, crossing the bulk material from the solution side to the steel surface side, and $C_{\text {int }}$ and $R_{\text {int }}$ are used to account for the ionic motion in regions internal to the sample, including occluded pores [68]. Due to the high porosity of the present mortars, the response was believed to be dominated by $R_{\text {pore }}$. Then, at the steel interface, and because of the high alkalinity of the mortar, the circuit of a passive metal with defects (like in Figure $5 f$ ) was used. The circuit was, in fact, similar to what could be found in the literature [69].

The spectra showed two distinct regions, one at frequencies above $\sim 10 \mathrm{~Hz}$ with the resistive response of $R_{\text {pore }}$ and another below $\sim 10 \mathrm{~Hz}$, with the response of the steel surface, with one or two time constants. The impedance at high frequencies was relatively low $\left(\sim 500 \Omega \mathrm{cm}^{2}\right)$, not changing significantly with the time of immersion. These values reflected the high porosity of the mortars and the absence of any effect of LDH (at least in the amount added) in counteracting porosity. 
Table 2. Parameters determined by numerical fitting of the EIS spectra shown in Figure 8 with capacitances calculated using Equation (2).

\begin{tabular}{|c|c|c|c|c|c|c|c|c|c|c|c|}
\hline System & Time & $\begin{array}{c}R_{\text {pore }} \\
\left(\Omega \mathrm{cm}^{2}\right)\end{array}$ & $\begin{array}{c}Y_{0, p a s s} \\
\left(\mathrm{~F} \mathrm{~cm}^{-2} \mathrm{~s}^{\mathrm{n}-1}\right)\end{array}$ & $n_{\text {pass }}$ & 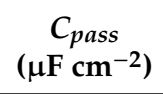 & $\begin{array}{c}R_{\text {pass }} \\
\left(\Omega \mathrm{cm}^{2}\right)\end{array}$ & $\begin{array}{c}Y_{0, d l} \\
\left(\mathrm{~F} \mathrm{~cm}^{-2} \mathrm{~s}^{\mathrm{n}-1}\right)\end{array}$ & $n_{d l}$ & $\begin{array}{c}C_{d l} \\
\left(\mu \mathrm{F} \mathrm{cm}^{-2}\right)\end{array}$ & $\begin{array}{c}R_{c t} \\
\left(\Omega \mathrm{cm}^{2}\right)\end{array}$ & $X^{2} / 10^{-4}$ \\
\hline \multirow{4}{*}{ Reference } & $1 \mathrm{~d}$ & 851 & $4.30 \times 10^{-5}$ & 0.980 & 40.2 & 802721 & - & - & - & - & 2.1 \\
\hline & $4 \mathrm{~d}$ & 518 & $1.19 \times 10^{-4}$ & 0.810 & 61.6 & 30565 & $1.85 \times 10^{-4}$ & 0.598 & 409 & $4.22 \times 10^{4}$ & 5 \\
\hline & $21 d$ & 589 & $1.24 \times 10^{-4}$ & 0.845 & 75.2 & 6515 & $2.50 \times 10^{-4}$ & 0.636 & 293 & $2.80 \times 10^{4}$ & 0.9 \\
\hline & $69 d$ & 661 & $1.59 \times 10^{-4}$ & 0.774 & 78.6 & 3860 & $7.73 \times 10^{-4}$ & 0.615 & 1457 & $4.61 \times 10^{4}$ & 1 \\
\hline \multirow{3}{*}{$\mathrm{LDH}-\mathrm{NO}_{3}$} & $19 d$ & 468 & $1.07 \times 10^{-4}$ & 0.854 & 63.9 & 75078 & $2.04 \times 10^{-4}$ & 0.902 & 260 & $1.21 \times 10^{5}$ & 16 \\
\hline & $28 \mathrm{~d}$ & 524 & $1.22 \times 10^{-4}$ & 0.790 & 58.2 & 39152 & $2.88 \times 10^{-5}$ & 0.942 & 28.3 & $8.47 \times 10^{4}$ & 1.8 \\
\hline & $72 d$ & 481 & $1.97 \times 10^{-4}$ & 0.730 & 81.4 & 15423 & $5.42 \times 10^{-5}$ & 0.460 & 43.3 & $1.12 \times 10^{6}$ & 2.4 \\
\hline \multirow{4}{*}{$\mathrm{LDH}_{-\mathrm{NO}_{2}}$} & $4 \mathrm{~d}$ & 474 & $5.17 \times 10^{-5}$ & 0.987 & 49.2 & 998436 & - & - & - & - & 2 \\
\hline & $13 d$ & 444 & $1.12 \times 10^{-4}$ & 0.876 & 73.3 & 402510 & - & - & - & - & 3 \\
\hline & $20 \mathrm{~d}$ & 491 & $1.37 \times 10^{-4}$ & 0.827 & 77.4 & 17441 & $4.56 \times 10^{-5}$ & 0.658 & 36.5 & $8.00 \times 10^{4}$ & 0.7 \\
\hline & $64 d$ & 450 & $1.63 \times 10^{-4}$ & 0.808 & 86.9 & 15241 & $3.40 \times 10^{-6}$ & 0.936 & 40.2 & $1.79 \times 10^{5}$ & 0.8 \\
\hline
\end{tabular}

Note: $R_{\text {pore }}$ is the pore resistance in the equivalent circuit of Figure 9 . 

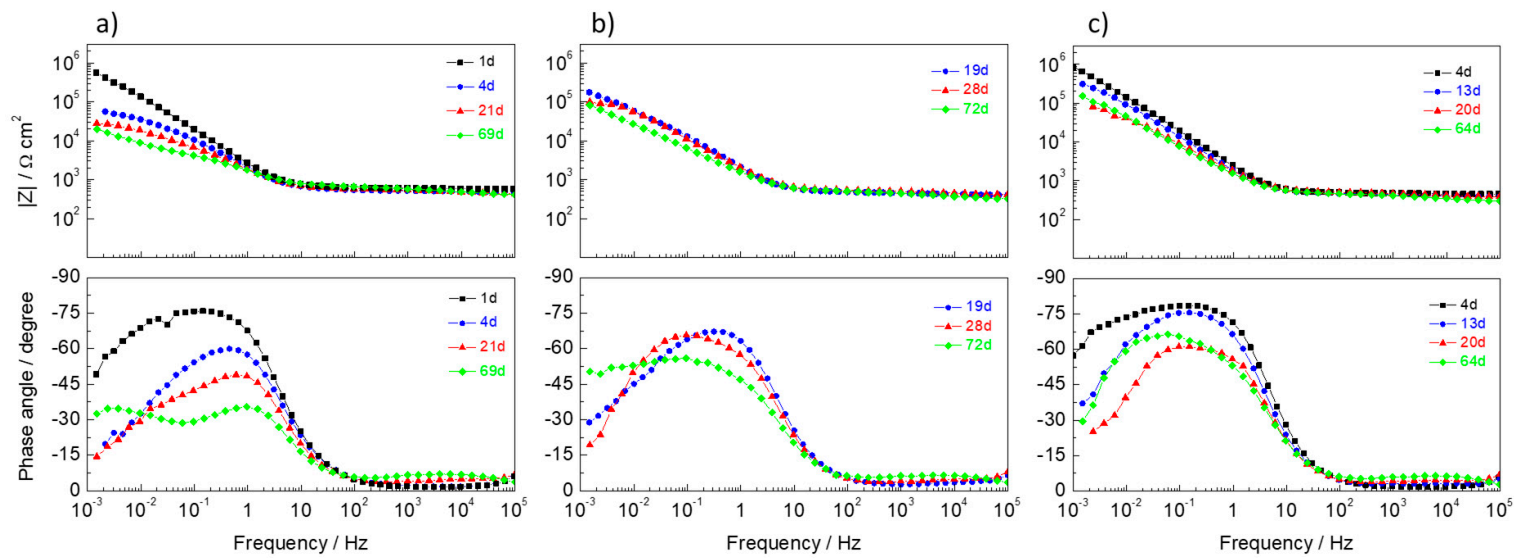

Figure 8. Impedance response of mortars with steel bar immersed in $3.5 \% \mathrm{NaCl}$ : (a) Mortar without $\mathrm{LDH}$ (reference), (b) mortar with $0.3 \% \mathrm{ZnAl}-\mathrm{NO}_{3}$ (2\% with respect to cement), (c) mortar with $0.3 \%$ $\mathrm{ZnAl}-\mathrm{NO}_{2}$ (2\% with respect to cement).

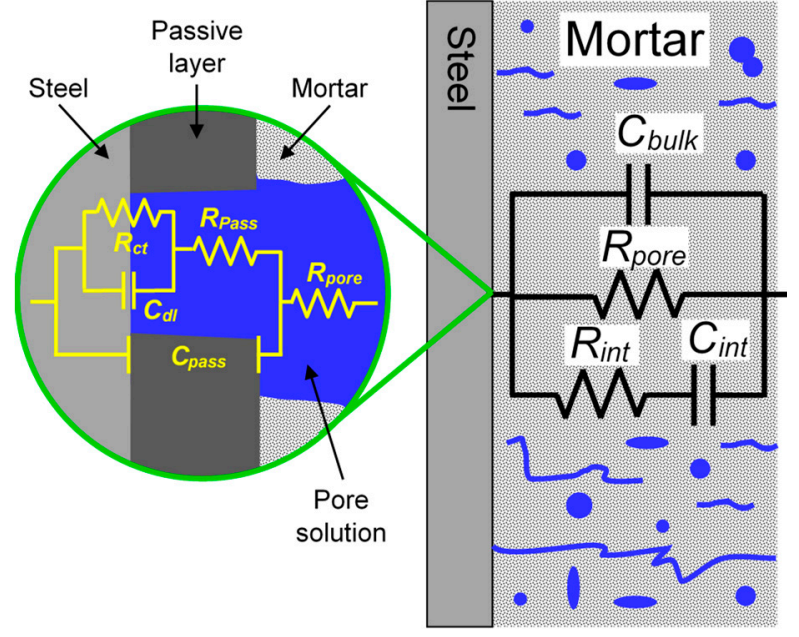

Figure 9. The equivalent electric circuit used for describing the impedance of mortar with a steel bar.

Regarding the response of steel, the reference sample (Figure 8a) started with a capacitive behavior due to the initial passive state of the rebar, but a noticeable decrease in impedance occurred in just a few days together with the appearance of a second time constant at lower frequencies, revealing the onset of localized corrosion as a result of the fast entrance of chloride ions through the porous mortar. The samples with LDH (Figure 8b,c) were able to keep the impedance at higher values. Even when a second time constant was detected at low frequencies, impedance remained higher compared to the reference mortar. After 2 months of immersion, the $R_{c t}$ of samples with LDH were $1-2 \times 10^{5} \Omega \mathrm{cm}^{2}$, about 2-4 times higher than the reference. Due to the smaller amount of chloride ions inside the mortar compared to the study in solution (Section 3.4), the LDHs seemed to be playing a role in capturing chloride ions, thus increasing the corrosion resistance of the steel bar (fewer chloride ions to attack the passive layer-higher $R_{\text {pass }}$-and less area under corrosion—higher $R_{c t}$ ).

These are the preliminary results of experiments performed with a limited number of samples (2-3 of each system) and a small addition of LDH to the mortars ( $0.3 \%$ of total mass). A more comprehensive study is presently being conducted.

\subsection{Final Remarks}

This work shows that $\mathrm{ZnAl}-\mathrm{NO}_{2}$ can be used to control the corrosion of steel in aqueous solution. However, it also shows that at the high $\mathrm{pH}$ of concrete, the $\mathrm{ZnAl}-\mathrm{LDHs}$ partially dissolves, and $\mathrm{OH}^{-}$is 
exchanged preferentially to chloride. These two facts have a direct impact on the use of these LDHs to control the corrosion of steel in mortar and concrete but are often neglected in studies in the field.

The partial dissolution at high $\mathrm{pH}$ and the preferential exchange by $\mathrm{OH}^{-}$suggest that these $\mathrm{LDH}$ might not be adequate for use in cementitious materials. Contrariwise, some works in the literature report higher corrosion resistance and durability of mortar and concrete with LDH $[16,31,43]$. The results in this work with sensors and steel bars embedded in mortars showed lower chloride penetration and higher corrosion resistance on samples with these LDH. At the moment, it is not possible to conciliate the absence of LDH effect suggested by the results in a solution with the positive effects observed in mortars. These effects might not come from the LDH structure but from chemical reactions with the ions dissolved from the LDH. It appears that the LDH chemistry alone cannot explain the action inside the concrete, and other reactions might take place, leading to the observed improvement in the performance. This is currently under investigation and will be reported in due time.

\section{Conclusions}

The results of this work confirmed the ability of ZnAl-LDH to capture chloride ions from solution and release nitrate/nitrite ions in their place. The ion exchange reaction was very fast, occurring in just a few minutes. This process was $\mathrm{pH}$-dependent and stopped at high $\mathrm{pH}$ due to the partial dissolution of $\mathrm{LDH}$ and the preferential exchange of $\mathrm{OH}^{-}$ions. The higher corrosion resistance of steel was observed when $\mathrm{ZnAl}-\mathrm{NO}_{2}$ was added to the aqueous solution. $\mathrm{ZnAl}-\mathrm{NO}_{3}$ did not produce any noticeable effect.

The $\mathrm{LDH}$ powders dissolved partially at $\mathrm{pH}>12$. Particles around $\sim 25 \mu \mathrm{m}$ delayed the curing of cement, while larger agglomerates $(>125 \mu \mathrm{m})$ allowed the same hardening time as the reference mortar (without LDH). The delay was attributed to the dissolution of $\mathrm{Zn}^{2+}$ ions from the $\mathrm{LDH}$ and their interference with the cement hydration reaction.

The partial dissolution and preferential capture of $\mathrm{OH}^{-}$at high $\mathrm{pH}$ can compromise the use of these LDHs in concrete. However, preliminary results showed lower penetration of chloride ions and higher resistance to corrosion of steel rebars. A more comprehensive study is currently underway.

Author Contributions: C.G., Z.M., and A.B. conceived and designed the experiments; F.M. and C.R. synthesized the LDH; C.G., Z.M., and R.S. performed the experiments; C.G., Z.M., and A.B. treated and analyzed the data; A.B., J.T., and M.F. supervised the work; A.B. and C.G. wrote the first draft of the manuscript. All authors have read and agreed to the published version of the manuscript.

Funding: This work was funded by the HORIZON 2020 collaborative project "LORCENIS" (Long Lasting Reinforced Concrete for Energy Infrastructure under Severe Operating Conditions, Grant agreement $\mathrm{n}^{\circ}$ 685445) and within the scope of the project CICECO-Aveiro Institute of Materials-UIDB/50011/2020 and UIDP/50011/2020-Financed by national funds through the FCT/MEC and when appropriate co-financed by FEDER under the PT2020 Partnership Agreement. AB acknowledges FCT—Fundação para a Ciência e a Tecnologia, I.P., in the scope of the framework contract foreseen in the numbers 4, 5, and 6 of the article 23, of the Decree-Law 57/2016, of August 29, changed by Law 57/2017, of July 19. ZM thanks COST action 15202 for a Short Term Scientific Mission to the University of Aveiro.

Conflicts of Interest: Authors FM and CR were employed by the company Smallmatek. The remaining authors declare that the research was conducted in the absence of any commercial or financial relationships that could be construed as a potential conflict of interest.

\section{References}

1. Darwin, D.; Dolan, C.W.; Nilson, A.H. Design of Concrete Structures, 15th ed.; McGraw-Hill: New York, NY, USA, 2016.

2. Bertolini, L.; Elsener, B.; Pedeferri, P.; Redaelli, E.; Polder, R. Corrosion of Steel in Concrete, Prevention, Diagnosis, Repair, 2nd ed.; Wiley-VCH Verlag GmbH \& Co. KGaA: Weinheim, Germany, 2014.

3. Broomfield, J.P. Corrosion of Steel in Concrete, Understanding, Investigation and Repair, 2nd ed.; Taylor and Francis: London, UK; New York, NY, USA, 2007.

4. Poursaee, A. Corrosion of Steel in Concrete Structures; Woodhead Publishing: Amsterdam, The Netherlands, 2016.

5. Angst, U.; Elsener, B.; Larsen, C.K.; Vennesland, Ø. Critical chloride content in reinforced concrete-A review. Cem. Concr. Res. 2009, 39, 1122-1138. [CrossRef] 
6. Elsener, B.; Zurich, E. Corrosion of Reinforcement in Concrete: Mechanisms, Monitoring, Inhibitors and Rehabilitation Techniques, EFC38; Raupach, M., Elsener, B., Polder, R., Mietz, J., Eds.; Woodhead Publishing Ltd.: Cambridge, UK, 2007.

7. Elsener, B. Corrosion Inhibitors for Steel in Concrete: State of the Art Report, EFC3; Maney Publishing: London, UK, 2001.

8. Duan, X.; Evans, D.G. Layered Double Hydroxides; Springer: Berlin/Heidelberg, Germany, 2006.

9. Rives, V. (Ed.) Layered Double Hydroxides: Present and Future; Nova Science Publishers: New York, NY, USA, 2001.

10. Cavani, F.; Trifiro, F.; Vaccari, A. Hydrotalcite-type anionic clays: Preparation, properties and applications. Catal. Today 1991, 11, 173-301. [CrossRef]

11. Fan, G.; Li, F.; Evans, D.G.; Duan, X. Catalytic Applications of Layered Double Hydroxides: Recent Advances and Perspectives. Chem. Soc. Rev. 2014, 43, 7040-7066. [CrossRef]

12. Tedim, J.; Kuznetsova, A.; Salak, A.N.; Montemor, F.; Snihirova, D.; Pilz, M.; Zheludkevich, M.L.; Ferreira, M.G.S. Zn-Al layered double hydroxides as chloride nanotraps in active protective coatings. Corros. Sci. 2012, 55, 1-4. [CrossRef]

13. Tedim, J.; Poznyak, S.K.; Kuznetsova, A.; Raps, D.; Hack, T.; Zheludkevich, M.; Ferreira, M.G.S. Enhancement of Active Corrosion Protection via Combination of Inhibitor-Loaded Nanocontainers. ACS Appl. Mater. Interfaces 2010, 2, 1528-1535. [CrossRef] [PubMed]

14. Buchheit, R.G.; Guan, H.; Mahajanam, S.; Wong, F. Active corrosion protection and corrosion sensing in chromate-free organic coatings. Progr. Org. Coat. 2003, 47, 174-182. [CrossRef]

15. Tedim, J.; Zheludkevich, M.L.; Salak, A.N.; Lisenkov, A.; Ferreira, M.G.S. Nanostructured LDH-container layer with active protection functionality. J. Mater. Chem. 2011, 21, 15464-15470. [CrossRef]

16. Tatematsu, H.; Sasaki, T. Repair materials system for chloride-induced corrosion of reinforcing bars. Cem. Concr. Compos. 2003, 25, 123-129. [CrossRef]

17. Raki, L.; Beaudoin, J.J.; Mitchell, L. Layered double hydroxide-like materials: Nanocomposites for use in concrete. Cem. Concr. Res. 2004, 34, 1717-1724. [CrossRef]

18. Xu, S.; Chen, Z.; Zhang, B.; Yu, J.; Zhang, F.; Evans, D.G. Facile preparation of pure CaAl-layered double hydroxides and their application as a hardening accelerator in concrete. Chem. Eng. J. 2009, 155, 881-885. [CrossRef]

19. Raki, L.; Alizadeh, A.R. Hydration of cement systems in the presence of novel LDH nanocomposite. Am. Concr. Inst. 2016, 312, 104-115.

20. Ke, X.; Bernal, S.A.; Provis, J.L. Controlling the reaction kinetics of sodium carbonate-activated slag cements using calcined layered double hydroxides. Cem. Concr. Res. 2016, 81, 24-37. [CrossRef]

21. Cao, L.; Guo, J.; Tian, J.; Xu, Y.; Hu, M.; Wang, M.; Fan, J. Preparation of Ca/Al-layered double hydroxide and the influence of their structure on early strength of cement. Constr. Build. Mater. 2018, 184, 203-214. [CrossRef]

22. Shui, Z.; Ma, J.; Chen, W.; Gao, X. The effect of layered double hydroxides on the concrete resistance of chloride-ion penetration. Key Eng. Mat. 2012, 509, 99-105. [CrossRef]

23. Kayali, O.; Khan, M.S.H.; Sharfuddin Ahmed, M. The role of hydrotalcite in chloride binding and corrosion protection in concretes with ground granulated blast furnace slag. Cem. Concr. Comp. 2012, 34, 936-945. [CrossRef]

24. Duan, P.; Shui, Z.; Chen, G. Influence of LDHs on chloride ion binding in cementitious materials. Key Eng. Mat. 2014, 599, 34-38. [CrossRef]

25. Yang, Z.; Fischer, H.; Polder, R. Modified hydrotalcites as a new emerging class of smart additive of reinforced concrete for anticorrosion applications: A literature review. Mater. Corros. 2013, 64, 1066-1074. [CrossRef]

26. Yang, Z.; Fischer, H.; Polder, R. Synthesis and characterization of modified hydrotalcites and their ion exchange characteristics in chloride-rich simulated concrete pore solution. Cem. Concr. Comp. 2014, 47, 87-93. [CrossRef]

27. Yoon, S.; Moon, J.; Bae, S.; Duan, X.; Giannelis, E.P.; Monteiro, P.M. Chloride adsorption by calcined layered double hydroxides in hardened Portland cement paste. Mater. Chem. Phys. 2014, 145, 376-386. [CrossRef]

28. Yang, Z.; Fischer, H.; Polder, R. Laboratory investigation of the influence of two types of modified hydrotalcites on chloride ingress into cement mortar. Cem. Concr. Compos. 2015, 58, 105-113. [CrossRef] 
29. Khan, M.S.H.; Kayali, O.; Troitzsch, U. Chloride binding capacity of hydrotalcite and the competition with carbonates in ground granulated blast furnace slag concrete. Mater. Struct. 2016, 49, 4609-4619. [CrossRef]

30. Yang, Z.; Fischer, H.; Cerezo, J.; Mol, J.M.C.; Polder, R. Modified hydrotalcites for improved corrosion protection of reinforcing steel in concrete-Preparation, characterization, and assessment in alkaline chloride solution. Mater. Corros. 2016, 67, 721-738. [CrossRef]

31. Yang, Z.; Polder, R.; Mol, J.M.C. Modified hydrotalcites as chloride scavengers and inhibitor release agents for improved corrosion protection of reinforced concrete. Heron 2017, 62, 61-83.

32. Ke, X.; Bernal, S.A.; Provis, J.L. Uptake of chloride and carbonate by $\mathrm{Mg}-\mathrm{Al}$ and Ca-Al layered double hydroxides in simulated pore solutions of alkali-activated slag cement. Cem. Concr. Res. 2017, 100, 1-13. [CrossRef]

33. Chi, L.; Wang, Z.; Zhou, Y.; Lu, S.; Yao, Y. Layered double hydroxides precursor as chloride inhibitor: Synthesis, characterization, assessment of chloride adsorption performance. Materials 2018, 11, 2537. [CrossRef] [PubMed]

34. Qu, Z.Y.; Yu, Q.L.; Brouwers, H.J.H. Relationship between the particle size and dosage of LDHs and concrete resistance against chloride ingress. Cem. Concr. Res. 2018, 105, 81-90. [CrossRef]

35. Xu, J.; Song, Y.; Zhao, Y.; Jiang, L.; Mei, Y.; Chen, P. Chloride removal and corrosion inhibitions of nitrate, nitrite intercalated $\mathrm{MgAl}$ layered double hydroxides on steel in saturated calcium hydroxide solution. Appl. Clay Sci. 2018, 163, 129-136. [CrossRef]

36. Machner, A.; Zajac, M.; Ben Haha, M.; Kjellsen, K.O.; Geiker, M.R.; De Weerdt, K. Chloride-binding capacity of hydrotalcite in cement pastes containing dolomite and metakaolin. Cem. Concr. Res. 2018, 107, 163-181. [CrossRef]

37. Chen, Y.; Yu, R.; Wang, X.; Chen, J.; Shui, Z. Evaluation and optimization of ultra-high-performance concrete (UHPC) subjected to harsh ocean environment: Towards an application of layered double hydroxides (LDHs). Constr. Build. Mater. 2018, 177, 51-62. [CrossRef]

38. Wu, B.; Zuo, J.; Dong, B.; Xing, F.; Luo, C. Study on the affinity sequence between inhibitor ions and chloride ions in $\mathrm{MgAl}$ layer double hydroxides and their effects on corrosion protection for carbon steel. Appl. Clay Sci. 2019, 180, 105-181. [CrossRef]

39. Wang, D.; Zhu, Q.; Su, Y.; Li, J.; Wang, A.; Xing, Z. Preparation of MgAlFe-LDHs as a deicer corrosion inhibitor to reduce corrosion of chloride ions in deicing salts. Ecotoxicol. Env. Saf. 2019, 174, 164-174. [CrossRef] [PubMed]

40. Chung, C.W.; Jung, H.Y.; Kwon, J.H.; Jang, B.K.; Kim, J.H. Use of calcium aluminum-layered double hydroxide to control chloride ion penetration of cement-based materials. J. Struct. Integr. Maint. 2019, 4, 37-42. [CrossRef]

41. Chen, L.; Chen, X.; Chen, W. Research on the carbonation of cement paste modified with layered double hydroxides. Appl. Mech. Mater. 2012, 174-177, 706-710. [CrossRef]

42. Duan, P.; Chen, W.; Ma, J.; Shui, Z. Influence of layered double hydroxides on microstructure and carbonation resistance of sulphoaluminate cement concrete. Const. Build. Mat. 2013, 48, 601-609. [CrossRef]

43. Cao, Y.; Dong, S.; Zheng, D.; Wang, J.; Zhang, X.; Du, R.; Song, G.; Lin, C. Multifunctional inhibition based on layered double hydroxides to comprehensively control corrosion of carbon steel in concrete. Corros. Sci. 2017, 126, 166-179. [CrossRef]

44. Shui, Z.H.; Yu, R.; Chen, Y.X.; Duan, P.; Ma, J.T.; Wang, X.P. Improvement of concrete carbonation resistance based on a structure modified Layered Double Hydroxides (LDHs): Experiments and mechanism analysis. Const. Build. Mat. 2018, 176, 228-240. [CrossRef]

45. Duan, P.; Yan, C.; Zhou, W. Effects of calcined layered double hydroxides on carbonation of concrete containing fly ash. Const. Build. Mat. 2018, 160, 725-732. [CrossRef]

46. Zuo, J.; Wu, B.; Luo, C.; Dong, B.; Xing, F. Preparation of MgAl layered double hydroxides intercalated with nitrite ions and corrosion protection of steel bars in simulated carbonated concrete pore solution. Corros. Sci. 2019, 152, 120-129. [CrossRef]

47. Ma, J.; Duan, P.; Ren, D.; Zhou, W. Effects of layered double hydroxides incorporation on carbonation resistance of cementitious materials. J. Mater. Res. Technol. 2019, 8, 292-298. [CrossRef]

48. Cao, Y.; Zheng, D.; Dong, S.; Zhang, F.; Lin, J.; Wang, C.; Lin, C. A composite corrosion inhibitor of MgAl layered double hydroxides co-intercalated with hydroxide and organic anions for carbon steel in simulated carbonated concrete pore solutions. J. Electrochem. Soc. 2019, 166, C3106-C3113. [CrossRef] 
49. Mei, Y.; Xu, J.; Jiang, L.; Tan, Q. Enhancing corrosion resistance of epoxy coating on steel reinforcement by aminobenzoate intercalated layered double hydroxides. Prog. Org. Coat. 2019, 134, 288-296. [CrossRef]

50. Li, Y.; Wu, S.; Liu, Q.; Nie, S.; Li, H.; Dai, Y.; Pang, L.; Li, C.; Zhang, A. Field evaluation of LDHs effect on the aging resistance of asphalt concrete after four years of road service. Const. Build. Mater. 2019, 208, 192-203. [CrossRef]

51. Tian, Y.; Dong, C.; Wang, G.; Cheng, X.; Li, X. Zn-Al-NO 2 layered double hydroxide as a controlled-release corrosion inhibitor for steel reinforcements. Mater. Lett. 2019, 236, 517-520. [CrossRef]

52. Cao, Y.; Zheng, D.; Luo, J.; Zhang, F.; Dong, S.; Pan, J.; Lin, C. Insight into the fabrication of ZnAl layered double hydroxides intercalated with organic anions and their corrosion protection of steel reinforced concrete. J. Electrochem. Soc. 2019, 166, C617. [CrossRef]

53. Prevot, V.; Forano, C.; Besse, J.P.; Abraham, F. Syntheses and Thermal and Chemical Behaviors of Tartrate and Succinate Intercalated Zn3Al and Zn2Cr Layered Double Hydroxides. Inorg. Chem. 1998, 37, 4293-4301. [CrossRef]

54. Galvão, T.L.P.; Neves, C.S.; Caetano, A.P.F.; Maia, F.; Mata, D.; Malheiro, E.; Ferreira, M.J.; Bastos, A.C.; Salak, A.N.; Gomes, J.R.B.; et al. Control of crystallite and particle size in the synthesis of layered double hydroxides: Macromolecular insights and a complementary modeling tool. J. Colloid Interf. Sci. 2016, 468, 86-94. [CrossRef]

55. Miyata, S. Anion-exchange properties of hydrotalcite-like compounds. Clays Clay Miner. 1983, 31, 305-311. [CrossRef]

56. Chen, Y.; Shui, Z.; Chen, W.; Chen, G. Chloride binding of synthetic Ca-Al-NO 3 LDHs in hardened cement paste. Const. Build. Mater. 2015, 93, 1051. [CrossRef]

57. Reddi, B.A.J. Why is saline so acidic (and does it really matter?). Int. J. Med. Sci. 2013, 10, 747-750. [CrossRef]

58. Morel, F.M.M.; Hering, J.G. Principles and Applications of Aquatic Chemistry; John Wiley and Sons: Hoboken, NJ, USA, 1993; p. 157.

59. Orazem, M.E.; Tribollet, B. Electrochemical Impedance Spectroscopy, 2nd ed.; John Wiley \& Sons: Hoboken, NJ, USA, 2017.

60. Brug, G.J.; van den Eeden, A.L.G.; Sluyters-Rehbach, M.; Sluyters, J.H. The analysis of electrode impedances complicated by the presence of a constant phase element. J. Electroanal. Chem. 1984, 176, 275. [CrossRef]

61. Barnes, P.; Bensted, J. Structure and Performance of Cement; Jawed, I., Skalny, J., Young, J.F., Barnes, P., Eds.; Applied Science Publishers: Barking, UK, 1983; p. 237.

62. Stephan, D.; Maleki, H.; Knöfel, D.; Eber, B.; Härdtl, R. Influence of Cr, Ni, and Zn on the properties of pure clinker phases: Part, I. C3S. Cem. Concr. Res. 1999, 29, 545. [CrossRef]

63. Asavapisit, S.; Fowler, G.; Cheeseman, C.R. Solution chemistry during cement hydration in the presence of metal hydroxide wastes. Cem. Concr. Res. 1997, 27, 1249. [CrossRef]

64. Trezza, M.A. Hydration study of ordinary Portland cement in the presence of zinc ions. Mater. Res. 2007, 10, 331-334. [CrossRef]

65. Andrade, C.; Diez, J.M.; Alonso, C. Mathematical modeling of a concrete surface "skin effect" on diffusion in chloride contaminated media. Adv. Cem. Bas. Mater. 1997, 6, 39-44. [CrossRef]

66. Sandberg, P.; Tang, L.; Andersen, A. Recurrent studies of chloride ingress in uncracked marine concrete at various exposure times and elevations. Cem. Conc. Res. 1998, 28, 1489-1503. [CrossRef]

67. De Weerdt, K.; Orsáková, D.; Müller, A.C.A.; Larsen, C.K.; Pedersen, B.; Geiker, M.R. Towards the understanding of chloride profiles in marine exposed concrete, impact of leaching and moisture content. Constr. Build. Mater. 2016, 120,418-431. [CrossRef]

68. Cabeza, M.; Merino, P.; Miranda, A.; Novoa, X.R.; Sanchez, I. Impedance spectroscopy study of hardened Portland cement paste. Cem. Concr. Res. 2002, 32, 881-891. [CrossRef]

69. Fan, L.; Meng, W.; Teng, L.; Khayat, K.H. Effect of steel fibers with galvanized coatings on corrosion of steel bars embedded in UHPC. Compos. Part B Eng. 2019, 177, 107445. [CrossRef]

(C) 2020 by the authors. Licensee MDPI, Basel, Switzerland. This article is an open access article distributed under the terms and conditions of the Creative Commons Attribution (CC BY) license (http://creativecommons.org/licenses/by/4.0/). 